\title{
Reflection of the national linguistic world view in the school course "Russian as a native language"
}

\author{
Tatiana Voiteleva ${ }^{1, *}$ \\ ${ }^{1}$ Moscow Region State University, 10A Radio str., 105005, Moscow, Russia
}

\begin{abstract}
The article is devoted to the problem of reflection of the national linguistic world view in the school course "Russian as a native language". The purpose of the study is to characterize the content of the school course of the Russian language, which contributes to the formation of the concept of the native language as a spiritual, moral and cultural value of the nation. The main issues of the content of the Russian as a native language course, reflecting the national linguistic world view, are defined and described. It is noted that the content aspect of education is distinguished by the strengthening of the value orientation of education.
\end{abstract}

\section{Introduction}

Modern pedagogy involves an axiological approach, the basis of which is the individual as an important value of society and the purpose of social development. From this perspective, education is a combination of moral, cultural and ethical orientations of a person who is able to adapt, which is, on the one hand, a means of transmission of culture, and on the other hand, contributes to the formation of a new culture. Basing on the interaction between education and culture, students form the perceptual unity of the surrounding reality. The approach, in which the main attention is paid to the development of values of material and spiritual culture, predetermined the transition from a knowledgecentered learning paradigm to a culture-congruent one and the establishment of a culturological orientation in teaching the Russian language.

According to the order of Federal Ministry of Education and Science of December 31, 2015, Federal State Educational Standard (FSES) was amended to single out the subject areas "The native language and literature" as subjects that are independent and mandatory for study.

The Russian language is the native language of the Russian people and the basis of its psyche. It is regarded as a means of forming and uniting the nation, connecting generations, ensuring continuity and constant renewal of the national culture. The academician Dmitry Sergeyevich Likhachov called the native language the "greatest value". The transmission of cultural patterns and means of human interaction with the surrounding environment to future generations is a great part of human life. Describing the language as an integral part

\footnotetext{
${ }^{*}$ Corresponding author: doptaganka@yandex.ru
} 
of culture that forms national identity, which is presented in speech, Fedor Ivanovich Buslaev noted that "the native language is an inexhaustible treasury of all spiritual existence of humankind..." [1, 4-5].

\section{Materials and methods}

As a social phenomenon, a language is the property of all people, that are part of society, the primary element of fiction, as well as a means with the help of which a writer creates artistic images and describes views of life. Knowledge of the language allows to understand the beauty, richness, expressiveness of native speech, which are most clearly manifested in literary texts. A native language acts as a means of world perception and a form of human activity, ensuring the development of intellectual abilities and creativity of an individual. As a national phenomenon, the Russian language reflects the historical and spiritual development of the people, it allows to introduce the native culture to students, to form moral standards and values, which include not only material constructions, but also concepts of good and evil, as well as hospitality traditions and literary works. [2].

The most important objectives of teaching Russian as a native language is to introduce schoolchildren to the history of national language associated with the history of the people, the formation of cognitive interest, love and respect for the Russian language, and, therethrough, to the native culture [3]. At the present time, when one of the most urgent problems of society is the revival of cultural and moral values, "the national-cultural component in teaching the Russian language becomes one of the important method of developing the spiritual and moral world of a student, the value-oriented culture and national identity..." [4]. In accordance with this statement, the syllabus of Russian as a native language involves three main branches: information on Russian studies, sociocultural information, ethnoculturological information.

\section{THE MAIN BRANCHES}

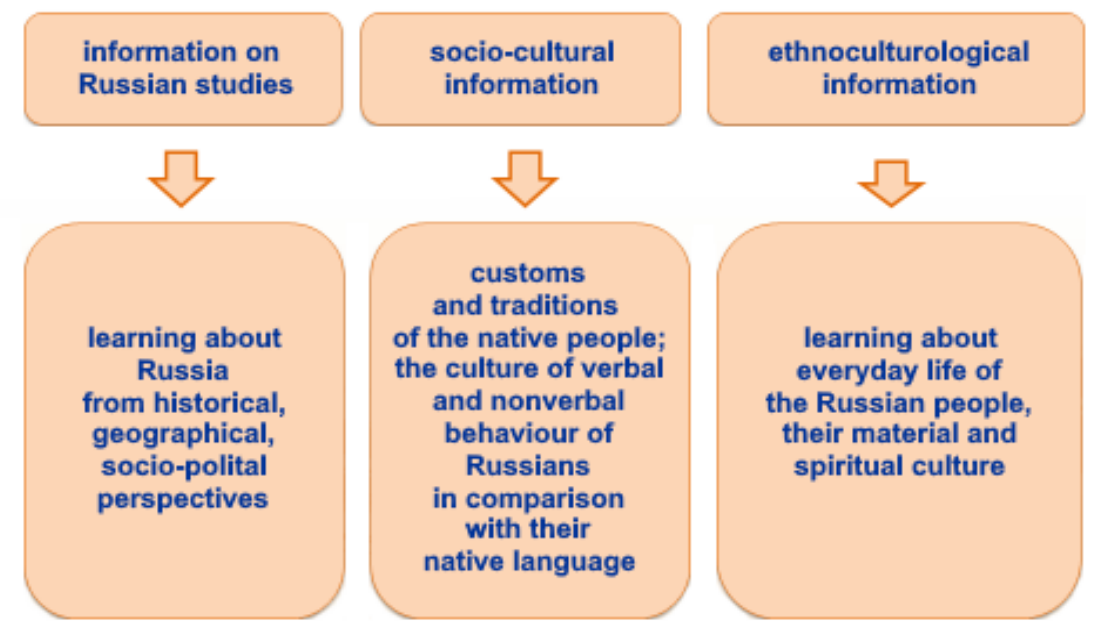

Fig. 1. The main branches of the syllabus of the course "Russian as a native language", that reflect the introduction of students to the national linguistic world view.

Deep knowledge of the native language involves the acquisition and understanding of the world view which is reflected in this language and represents "an integral component of the national character" [5]. The concept of a linguistic world view traces its origin to the ideas 
of Wilhelm von Humboldt, who considered a language as a world existing between the world of external phenomena and the inner world of a person. In modern studies, the world view is regarded as a complete global image of the world that exists in consciousness of a person. The world view is of national nature and, as a mental formation, it requires specific forms of manifestation. A language is considered to be one such form. According to the national linguists Vereshchagina E.M., Kolesova V.V., Kostomarova V.G., Stepanova Iu.S., Teliia V.N., etc., the linguistic world view is the features of the native culture of the people, reflected in the language, as well as historically formed national values, national world outlook and perception of the surrounding reality with its images, concepts and symbols.

"Linguistic world view is the common cultural patrimony, it is structured and consists of multiple level. The linguistic world view determines the communicative behavior, understanding of the external world and the internal world of a person. It reflects the means of speech and cognitive activity peculiar to a particular epoch with its spiritual, cultural and national values" [6].

In the educational process, the concept of the world view is directly related to the culturological component in learning the Russian language.

\section{Discussion}

Any language has its national world view. According to the academician Shcherba L.V., "each language presents us the external world, the perceived world in its special form..." [7]. The linguistic world view reflects the individual world view of a particular person as well as the knowledge, experience, and cultural heritage accumulated by humankind. The perception of the linguistic world view is influenced by various living conditions of the people, the traditions and features of the national character. National cultural specificity is manifested in the names of objects, phenomena, and events. Leontiev A.A. notes that "each language reflects the idea of the world, of what snow and water are, as well as the life and activity, the social practice of each nation. A language reflects the ideas of all people on how the world works" [8].

It should be pointed out that each word that is particularly significant for the national culture evokes certain associations, that is a number of other words related in the meaning. Thus, the associative field that includes words that are similar in the meaning is formed. Associations arise in the human consciousness as a response to a stimulus word and allow to determine the semantics of a polysemous word in a specific context. Introduction to the notions of "association", "the associative field" forms the students' associative thinking, enriches their vocabulary, develops speech and cognitive abilities.

The work on non-equivalent vocabulary, which cannot be translated into another language in one word, since a phenomenon or a concept is absent in other cultures, has become of particular importance in the formation of the national linguistic world view of students. Such vocabulary includes items of national cuisine, traditional clothing, geographical names, phraseological units, words from the field of folklore (тулуп (а sheepskin coat), окрошка (cold kvass soup with vegetables and cooked meat), балалайка (balalaika), самовар (samovar), гармонь (a squeezebox), крестины (a christening party), красна девица (a beautiful maiden), Кощей Бессмертный (Koschey the Immortal), первый блин - комом (lit. the first pancake is always lumpy), бить челом (to bow low), etc.). According to the scientists, such vocabulary accounts for 6-7 percent of the total number of the actively used vocabulary and is found when comparing languages [9]. Words of non-equivalent vocabulary can be translated into a foreign language, into English, in particular, by means of transliteration: матрёшка (matryoshka) or a descriptive translation: матрёшка - Russian doll; распутица — a season of bad roads. 
In folk poetry works, feelings of a person were conveyed allegorically - through poetic symbols that expressed the meaning of a phenomenon with objects, and words that helped to express the emotions, thoughts and mood of a person. Word-symbols were bonds that covered all spheres of human life and nature. Береза (a birch), утица (a duck), голубка сизая (a gray dove) were considered to be the symbols of a girl; symbols of a young man were дуб (an oak), голубь (a dove); хлеб (bread) was regarded as a symbol of prosperity, abundance and material welfare; шум леса, листьев (lit. Sounds of a forest and leaves) were the symbols of sadness. Переправа через реку (lit. river crossing) symbolized a romantic meeting. Цветущие растения (lit. Flowering plants) symbolized love, however, вянущие (lit. withering plants) denoted unanswered love and separation. Совместная еда, питье (lit. shared food and drinks) represented mutual love [10].

Colour symbolism is an important aspect of the visual perception of reality, which is based on the national history and culture. The choice of colour has always been of great importance in both everyday and protection tradition. For a long time, red and white have been the favorite colours in clothes of the Russian people. Red is the colour of life, a symbol of fire, beauty, and strength: Красно солнышко, дающее жизнь (lit. The great sun that gives life); Лето красное - торжество жизни (lit. Glorious summer is the celebration of life). White colour is a symbol of purity, innocence: Без правды жить бела света бежать (lit. To live without the truth is equal to running away from the world); Белую ворону и свои заклюют (lit. A white crow will be pecked to death by its own kind). Black colour symbolizes evil, sadness, loss: Черную душу и мылом не отмоешь (lit. Black soul cannot be washed with soap); Черный ворон бел для своих воронят (lit. Black raven is white for its little crows). In the protective culture, it was believed that the white colour could protect against evil spirits and prevent them from entering the house. With talismans, a person protected himself/herself and his/her home from adverse forces of nature, evil spirits and wild animals. In folklore, ancient apotropaic symbols which were depicted on clothes, have been preserved.

Folklife culture is always manifested in customs, in the furnishing and decoration of houses and churches, in songs and oral legends, in the works of peasant craft. The history of the Russian way of life is reflected in the native language, for instance, the Russian izba (a log house), the Russian stove, the Russian samovar - they all irretrievably recede into the past. Moreover, they are the basis of the national culture, therefore it is important to introduce students to domestic objects and Russian folk crafts: Khokhloma painting, Gzhel ceramics. The production of children's toys also has its own history. As a symbol of the Russian national culture, matryoshka appeared at the end of the 19th century in Sergiyev Posad, which is an ancient center of toy production. The Russian doll is still one of the most popular souvenirs in the world. Dymkovo toys (whistles in the form of animals, roosters, deer, skomorokhs, ladies with umbrellas and other clay figures); as well as Bogorodskoe toys (tiny figures of people and animals, often constituting compositions on fables and fairy tales) are known outside of Russia. Bogorodskoe Wood Carving, the folk craft of carving toys and sculptures made of soft wood (linden, alder, aspen), which originated in the village Bogorodskoe in Moscow Region, is also well-known in the Russian culture. Introduction to the national traditions and objects of folk art forms a cognitive interest, faith in the national ideal, as well as contributes to the development of aesthetic sense of students. National costumes are the richest cultural heritage, the property of museum collections.

The unique world view of the Russian people is reflected in the figurative expressions of the native language, that is phraseological units that contain information on the everyday life, traditions and customs, and the beliefs of a Russian person. Understanding the meaning of phraseological units and the ability to use them in speech contributes to the formation of the Russian linguistic identity, as well as strengthens the role of the native language as a 
means of uniting the nation, and is an important component in the development of a linguistic personality.

Furthermore, the Russian language is rich in striking figurative expressions, that is popular expressions, associated with historical events, that came into the native language from literature and folklore. The popular expressions come into the speech from history, folklore, and literature. These expressions include aphorisms, proverbs, sayings, utterances of historical figures, characters of fiction. For instance, there is the expression from the fable "The cook and the cat" by Krylov I.A.: A Васька слушает, да ест (lit. Tom listens, but still eats), which denotes ignoring other people's words, continuing doing actions that cause harm to someone. Or, there is another example from the fable "Casket": А ларчик просто открывался (lit. And the casket was easy to open from the very beginning), that is the problem that seemed complicated, had a simple solution. The sources of popular expressions include paintings by Russian artists. For example, there is a painting "The Knight at the Crossroads" by Vasnetsov V.M., which depicts a Russian warrior standing in front of a stone with symbolic names. A person who is called The Knight at the Crossroads encounters a hard life choice. The introduction to phraseological units and popular expressions develops students' understanding that the real meaning of a phrase could be hidden; students become interested in discovering this meaning, that is familiarizing with the native culture and national world view. In addition, schoolchildren obtain a motive for learning activity, and their creative initiative and creative thinking are developed.

One of the most effective methods of forming a national linguistic world view is to familiarize students with proverbs and sayings, that are short, accurate, figurative expressions with a didactic meaning [11]. Proverbs and sayings accompany a person throughout his/her life. They convey an emotional assessment of various life phenomena, expressing the unity of high art and an everyday language. This is the greatest asset of Russian spirituality. According to Likhachev D.S., proverbs contain the "Russianness" of the soul: На чужой стороне и весна не красна (lit. In a strange land, even spring does not seem lovely). Черную душу и мылом не отмоешь (lit. Black soul cannot be washed with soap). Рубашка беленька, да душа черненька (lit. The shirt is white, but the soul is black).

"There are various epochs that proverbs originated from. The diversity of human relations, which are imprinted in the precise folk sayings and aphorisms, is immense. From the abyss of time, the information on joy and suffering of people, laughter and tears, love and anger, faith and unbelief, verity and falsity, honesty and deceit, diligence and laziness, the beauty of truth and the ugliness of prejudice reached us in these succinct composite of reason and knowledge of life." [12].

It should be noted that, in different languages, there are proverbs that contain the same meaning. This indicates that people of different nationalities share common thoughts and dreams. For instance: Слезами горю не поможешь (lit. Crying will not mend matters) (Russian) - Слезами горя не смоешь (lit. Tears will not wash away the matter) (Tamil); Один летний день год кормит (lit. A summer day feeds a year) (Russian) - Один летний день зимний месяи кормит (lit. One summer day feeds a winter month) (Chechen). The comparison of proverbs and sayings of various nations allows to consider the phenomena of language and culture in the dialogue of cultures, which contributes to the awareness of national-cultural distinctions, as well as the formation of respect for the cultures of different nations. The dialogue of cultures in teaching the Russian language could be an important means for students to become aware of the diversity of the spiritual and material world, to recognize and understand values of another culture, and to develop the ability to live and communicate in a multiethnic country. The dialogue of cultures is not only a method of understanding a national culture, but also an insight into the own culture, since the awareness of the native linguistic world view is particularly manifested in comparison with 
the world view of another nation. While comparing different cultures, students become more deeply aware of the uniqueness of their native culture, as well as the common features that unite these cultures, and begin to feel the peculiarities and originality of the native language more profoundly and to love it consciously.

The body of knowledge and ideas of the Russian people on the world and themselves is reflected in riddles in an "encrypted" form. The riddle briefly and allegorically describes an object or a phenomenon. Riddles develop imagination, ingenuity and allow to see the unusual in the ordinary, and conversely, to notice the usual in the extraordinary. Riddles emerged in ancient times, when a person, by learning the nature, endowed it with the ability to feel, act and influence the person's life and destiny. It was believed that there was a leshy in the forest, a vodyanoy in the water, a kikimora in the swamp, a domovoy in the house. Under the influence of beliefs, an ancient person learned to speak indirectly, for instance, without naming animals, so that hunting would be successful. Using riddles, the elderly taught young people to memorize "secret" words. Riddles are constructed with the application of figures of speech, such as metaphors, simile, etc.: Стоит старичоккрасный колпачок (lit. There is an old man with a red cap); Сильнее солнща, слабее ветра, ног нет, а идёт, глаз нет, а плачет (lit. It is stronger than the sun, weaker than the wind, it has no legs, but walks, it has no eyes, but cries).

Dialect is an important part of Russian folk culture. Dialect vocabulary gives an idea of life, housekeeping, everyday life, customs and traditions of the inhabitants of a particular area. Dialects originated earlier than the standard language. They appeared in the 12th century and, having traveled a long path of development, are preserved to the present day.

Dialectisms are traditionally used in literature in order to demonstrate the details of everyday life of village people, as well as various aspects of the material culture of inhabitants of different regions of Russia, and the peculiarities of national perception of the world. It is worth mentioning that the standard language has been supplemented with dialectics from the field of village life, for example: борозда (a furrow), cmoг (a haystack), копна (a haycock), доярка (a milkmaid), ворковать (to соо), филин (an eagle owl), смекалка (ingenuity), etc. In literature, dialect words create a local colour, they are an important means of characterization of characters, conveying the features of their speech and expressing the author's attitude to the problems of folk culture.

Personal names of people are part of the national history and culture, since they reflect the folk beliefs, historical events, everyday life, and craft. Moreover, the interest in names, as well as the knowledge of their origin and meaning instil love for the history of the motherland, its people, its language and culture. Thus, for instance, it would be interesting for students to learn that one of the first Christian names in Russia was the name Vasilii, which was the name of grand prince Vladimir after his baptism. This name denotes "kingly", "royal". From ancient legends and folk tales, from bylinas and fairy tales in the Russian culture, the precedent names are known, which are used in speech as a symbol of certain qualities, events, destinies, being a reflection of the cultural-historical heritage of the nation, for example, Ivan the Fool, Baba Yaga, Vasilisa the Wise, etc. Precedent names are associated with the text, which is a cultural phenomenon that is widely known to the native speakers and acts as a symbol, indicating certain qualities of a person [13]. Such texts include Russian fairy tales, bylinas, legends and folk tales about historical events and heroes.

In Russian folklore, the concept of "oral prose" is applied, which combines reality and literature in the description of realities of life. One of the varieties of such prose is a true tale (бывальщина) which is a mythical narrative of various events in the real life of the people, which are intertwined with stories based on the visions and imaginations of a narrator. In the true tales, mysterious and inexplicable phenomena in nature and life, in addition to a person's encounter with supernatural beings with magic abilities, are 
described. The main objectives of mythical narratives are to warn of danger and protect from harm. They describe what could happen to a person if he/she makes a rash decision or violate a rule. Thus, a true tale contains peculiar rules of human behavior in the world of nature and people. A distinctive feature of the true tale language is the connotative vocabulary and dialectisms: нету (nothing), паразит (a bloodsucker), парнишка (a lad), плат (a headscarf), ково (whom), оне (the obsolete form of 'they'), конек (a roof ridge), which makes it possible for students to trace the richness of the native language, especially its use in colloquial speech. True tales are popular in a particular area. For instance, there are Ural household folklore in the works of Bazhov P.P., as well as the Siberian true tales in the works of Pukhnachev V.M.

Mastering the national linguistic world view, students get acquainted with the "cultural concept", which is the bearer of the cultural memory of the nation. In modern linguistics, the concept serves as a notional unit of culture and consciousness, which is manifested in a word as a system of meanings. As concepts, the words denoting phenomena of reality that are most important for a certain nation, are presented. The inclusion of this phenomenon in the syllabus is of great educational significance, since it allows to comprehend the concepts that are most relevant for the Russian culture and the Russian people: мир, душа, Родина, счастье, справедливость, тоска, судьба, etc (lit. Peace, soul, homeland, happiness, justice, sorrow, fate). Linguists regard the concepts as a link between the language personality and culture. The cultural concepts are words that contain the essence of the national-cultural world view of the nation, the assessment, the person's attitude to the reflected object, and other components [14].

In modern linguistics, the concept serves as a notional unit of consciousness and culture, which is manifested in a language and is an important component of the linguistic world view. As concepts, the words denoting phenomena of reality that are most important for a certain nation, are presented. The concept appears as an image that gradually transforms from a sensory image into a mental one. For instance, the image of the cold is the basis of the concept of "fear", therefore, the following expressions are observed in the Russian linguistic world view: дрожать от cmpaxa (lit. to quiver with fear), зуб на зуб не nonadaem (lit. teeth are chattering), мороз по коже nродираem (lit. the cold makes shudder), дрожь пробегает по спине (lit. a cold shiver ran down the spine), кровь стынет (lit. blood turns to ice), etc. [15]. The concepts include such notions as motherland, Rus', Russia; a person, identity; soul, conscience; peace, fire, water, bread, faith, love, joy, sadness, sorrow; truth, verity, kindness, etc. [16]. The word "road", which is associated with many omens of the Russian people, can be regarded as a cultural concept [17]. There is a tradition to sit down and be silent for a moment before a long journey. It is considered to be a good omen if a person starts on a long journey when it rains. The road theme is of particular importance in Russian folklore. The choice of a road denoted the choice of fate and the path of life for a character. A fairy-tale character stops at the crossroads near a stone that says what a person would find or lose on each of the roads. The road trope is also common in Russian proverbs and sayings: Труд и старание - дорога $\kappa$ ycnexy (lit. Work and diligence are the road to success); Зерно, растущее на дороге, никогда не созреет (lit. A grain that grows on the road will never ripen); Дорогу осилит идущий (lit. The one who walks will go the distance); Скатертью дорожка (lit. Let the road be like a tablecloth for you (Good riddance)), etc.

The purpose of the educational conceptual analysis of a word is the phased formation of system knowledge on the concept that exists in the consciousness of an individual as a member of a national culture. Such an analysis contributes to the formation of knowledge about the language system of the native language, enriches the vocabulary of students, teaches independent research, and finally, is a powerful factor that increases interest in learning the Russian language, knowledge of native culture. 
The national world view is experienced through reading and the text analysis. This could allow students to learn the social norms, as well as to understand the cultural values of nations, rules of behavior and culture of everyday communication in a multicultural society. Learning Russian as a native language involves the use of texts that could reflect the spiritual and moral values of Russians as a didactic material. This could allow students to learn the social norms, as well as to understand the cultural values of nations, rules of behavior and culture of everyday communication in a multicultural society. According to Likhachev D.S., "national characteristic of a people... are only discovered when viewed from the outside perspective and in comparison..." [18]. The text-centric approach to the Russian language teaching in which the text is regarded as a means of learning the language as a multifunctional phenomenon, familiarizing students with the Russian culture, as well as developing students' communicative and culturological competence and forming a Russian linguistic world view is considered to be of greatest importance [19]. The attention to the aesthetic component in language education contributes to the students' development of a sense of beauty, fosters an appreciation of the correct, beautifully sounding speech, which is necessary for the formation of a cultured person who is able to use the richness of the language, its sonority, expressiveness and relevance. Texts of different types (depending on the content) allow to influence the feelings of students, developing love for the motherland, loyalty to it, respect for other peoples, love for the native nature, etc.

\section{Results and conclusions}

The article has provided the consideration of the basis of the syllabus of the school course "Russian as a native language", aimed at forming students' understanding of the national linguistic world view, which would allow to determine that "a language is a powerful tool, which forms a crowd of people into an ethnic group, that constitutes a nation through preservation and transmission of culture, traditions, social consciousness" [20]. The reflection of the national linguistic world view in the school course on the Russian native language contributes to the education of a person with an active civil position, inextricably associated with a sense of love for the motherland, as well as the development of the spiritual and moral world of students.

\section{References}

1. F.I. Buslaev, O prepodavanii otechestvennogo iazyka (L., 1949)

2. D.S. Likhachev, Zemlia rodnaia (M., Direkt-Media, 2012)

3. Primernaia programma po uchebnomu predmetu «Russkii rodnoi iazyk» dlia obrazovatel'nykh organizatsii, realizuiushchikh programmy osnovnogo obshchego obrazovaniia. Reestr primernykh osnovnykh obshcheobrazovatel'nykh programm Ministerstva obrazovaniia i nauki Rossiiskoi Federatsii

4. E.A. Bystrova, S.I. L'vova, V.I. Kapinos, Obuchenie russkomu iazyku v shkole: Ucheb. posobie dlia studentov ped. vuzov (M., Drofa, 2004)

5. Iu.V. Cherniavskaia, Narodnaia kul'tura i natsional'naia traditsiia (Minsk, 1998)

6. V.A. Maslova, Vvedenie v kognitivnuiu lingvistiku: ucheb. Posob. (M., Flinta: Nauka, 2011)

7. L.V. Shcherba, Prepodavanie inostrannykh iazykov v srednei shkole. Obshchie voprosy metodiki (M.-L., 1947)

8. Psikhologiia obshcheniia (M., Academia, Smysl, 2008) 
9. E.M. Vereshchagin, V.G. Kostomarov, Iazyk i kul'tura (M., Indrik, 2005)

10. Iu.G. Kruglov, Russkii fol'klor (M., Sovetskii pisatel', 2000

11. T.M. Voiteleva, Vestnik MGGU im. M.A. Sholokhova 3 (2014)

12. M. Sholokhov, Sokrovishchnitsa narodnoi mudrosti. Poslovitsy russkogo naroda (M., 1957)

13. D.B. Gudkov, Pretsedentnoe imia i problemy pretsedentnosti (M., Izd-vo MGU, 1999)

14. V.N. Teliia, Russkaia frazeologiia. Semanticheskii, pragmaticheskii $i$ lingvokul'turologicheskii aspekty (M., 1996)

15. V.A. Maslova, Vvedenie v kognitivnuiu lingvistiku: ucheb. Posob. (M., Flinta: Nauka, 2011)

16. Iu.S. Stepanov, Konstanty: Slovar' russkoi kul'tury (M., Akademicheskii Proekt, 2004)

17. Iu.E. Prokhorov, Rossiia. Bol'shoi lingvostranovedcheskii slovar' (M., "Ast-Press", 2009)

18. D.S. Likhachev Zametki o russkom (M., Kolibri, Azbuka-Attikus, 2014)

19. E.A. Bystrova, S.I. L'vova, V.I. Kapinos, Obuchenie russkomu iazyku v shkole: Ucheb. posobie dlia studentov ped. vuzov (M., Drofa, 2004)

20. S.G. Ter-Minasova, Iazyk i mezhkul'turnaia kommunikatsiia (M., 2008) 